\title{
Genetic diversity among maize (Zea mays L.) landraces assessed by RAPD markers
}

\author{
Valdemar P. Carvalho ${ }^{1}$, Claudete F. Ruas ${ }^{2}$, Josué M. Ferreira ${ }^{2}$, Rosângela M.P. Moreira ${ }^{2}$ and Paulo M. Ruas ${ }^{2}$ \\ ${ }^{1}$ Departamento de Agronomia, Universidade Estadual de Londrina, Londrina, Paraná, Brazil. \\ ${ }^{2}$ Departamento deBiologia Geral, Universidade Estadual de Londrina, Londrina, Paraná, Brazil.
}

\begin{abstract}
The genetic relationships among 81 maize accessions consisting 79 landraces and two improved varieties, maintained by farmers in southern Brazil were investigated using Random Amplified Polymorphic DNA (RAPD). Thirty-two highly informative primers amplified 255 markers of which 184 (72.2\%) were polymorphics. Based on the RAPD markers, a dendrogram was constructed using the UPGMA method. The range of genetic similarity was from 0.78 to 0.91 . The molecular data grouped the accessions into two main clusters, which were correlated according to kernel colors. Small clusters were seen associated to characteristics, such as kernel morphology. The analysis of the molecular data revealed that maize management adopted by small-scale farmers has contributed to the maintenance of genetic variability and since field isolation is a regular practice, variety identities have been preserved. These results will be useful to establish and maintain a germplasm collection of landrace maize and may guide us in designing strategies that maximize the utility of maize genetic resources.
\end{abstract}

Key words: corn landrace, genetic variability, molecular genetic markers, RAPD.

Received: October 15, 2002; Accepted: February 6, 2004.

\section{Introduction}

Genetic erosion and habitat destruction by modern agriculture has increased the importance of germplasm characterization of plant materials. Therefore, it is imperative to rationalize conservation and use of genetic resources to guide in the establishment of strategies that ensure the maintenance of genetic variability that is essential in plant breeding. World collections of maize comprise about 12,000 accessions that are represented in 256 races, of which about 30 are in the process of extermination (Machado et al., 1998). It is estimated that only around 2\% of the maize germplasm is utilized in breeding programs and an important fraction is cultivated and conserved by small landholder farmers. While most of the genetic variability is represented within and between landraces maintained by the traditional family farming systems (Marshall, 1977), there was agreement, during the IV International Conference of Plant Genetic Resources in Germany (1996), that the main reason for accelerated genetic erosion was the substitution of maize landraces for a small number of improved varieties. Data reported by the Food and Agriculture Organization (FAO) in 1996 indicated that $20 \%$ of maize varieties from Mexico have disappeared since 1930. In ad-

Send correspondence to: Claudete F. Ruas. E-mail: ruas@ sercomtel.com.br. dition, $91 \%$ of maize varieties used in USA in the beginning of the $20^{\text {th }}$ century have also disappeared and today all production is based on less than ten hybrids.

Many racial complexes are considered important for maize improvement, including Dents of México (Tuxpeño, Vandeño, Tepecintle, Zapalote, Zapalote Chico, Grande and Celaya), Dents of the Corn Belt of the United States (Reid, Lancaster and Krug), Dents of Caribbean (Tusóns), Flints of Caribbean (Coastal, Tropical Flints, Comuns and Costeños), Catetos (flint orange colored maize from Brazil, Argentina and Uruguay), and Flint and Floury (maize from Northern United States and Southern Canada) (Paterniani et al., 2000). Today, maize germplasms are represented by 3,800 accessions of which approximately 288 are introductions, 222 are populations with some genetic improvement, and 1,783 are assessments from different Brazilian regions (Abadie et al., 2000).

Maize landraces and creolized varieties have been broadly and independently cultivated throughout Brazilian regions and they are of relevant socio-economic importance for the family farming systems. As a result, different accessions are developed and selected for different environments and morphological characteristics (Paterniani et al., 2000). The genetic diversity of landraces is, therefore, the most immediately useful part of maize biodiversity. However, more consistent agronomic and genetic knowl- 
edge about these collections is still lacking and it is a serious limitation to utilizing, managing, and conserving the landrace maize gene pools (Nass et al., 1993).

The development of modern plant breeding techniques has greatly facilitated wider use of a wealth of diversity from many sources including landraces, and especially, has allowed food production to keep up with population growth (Wood and Lanné, 1999). Currently, the genetic diversity of plants has been assessed more efficiently after the introduction of methods that reveal polymorphism directly from the biochemical and DNA levels. Markers based on isoenzymes (Prince et al., 1986; Lankey et al., 1997) and RFLP (Lee et al., 1989; Bernardo, 1994) were the first molecular markers used in maize breeding programs. More recently, markers based on polymerase chain reaction (PCR), such as random amplified polymorphic DNA or RAPD (Williams et al., 1990) have been used in analysis of genetic distance in several plant species (Sharma et al., 1995; Gunter et al., 1996; Lashermes et al., 1996; Samec and Nacinec, 1996; Irvin et al., 1998; Colombo et al., 2000). Comparisons among the different types of markers have contributed to the selecting of the most appropriate technique related to desired objectives. RAPD markers are commonly used because they are quick and simple to obtain, enabling genetic diversity analysis in several types of plant materials, such as natural populations, populations in breeding programs and germplasm collections (Ferreira and Grattapaglia, 1996). When compared with markers based on RFLP, RAPD markers have been shown to be equivalent in determining intraspecific genetic diversity among genotypes of Brassica oleracea L. However, RAPD markers were superior when simplicity and cost were considered (Dos Santos et al., 1994). Similar results were reported for estimating the genetic relationships among and within cruciferous species (Thormann et al., 1994). In maize, RAPD markers have been used in the analysis of genetic distance among segregant lines (Marsan et al., 1993) to predict the best crosses among lines for hybrid development (Lanza et al., 1997), and to assess genetic diversity among collections of native maize (Moeller and Schall, 1999).

The goal of this research was to investigate the level of genetic diversity in 79 cultivated accessions of maize landraces and two commercial varieties. This will contribute in identifying efficient strategies for the sustainable management of the genetic resources of the landraces in study.

\section{Materials and Methods}

\section{Plant material}

Plant material consists of 81 maize accessions, comprising two commercial varieties, developed at the Instituto Agronômico do Paraná (IAPAR), and 79 landraces obtained from the Assessoria e Serviços a Projetos em Agricultura Alternativa (AS-PTA), a non-governmental organization that coordinates a program for collection and conservation of maize landraces (Table 1). According to Nass and Paterniani (2000), only 14\% of the accessions of maize germplasm maintained in Brazil are used and little is known about the genetic variability of the different collec-

Table 1 - Accessions of maize studied, morphological characteristics and locality.

\begin{tabular}{|c|c|c|c|c|c|c|c|}
\hline Accessions & $\begin{array}{l}\text { Endosperm } \\
\text { color }\end{array}$ & Kernel type & $\begin{array}{c}\text { Flowering times } \\
\text { (days) }\end{array}$ & $\begin{array}{l}\text { Length kernel } \\
\text { (mm) }\end{array}$ & $\begin{array}{l}\text { Width kernel } \\
\quad(\mathrm{mm})\end{array}$ & $\begin{array}{l}\text { Thickness } \\
\text { kernel }(\mathrm{mm})\end{array}$ & City/State ${ }^{10}$ \\
\hline 1 - Asteca & yellow-orange & dent & 74 & medium & medium & short & Rio Azul/PR \\
\hline 2 - Asteca antigo do Prestupa & yellow-orange & dent & 78 & medium & medium & medium & Bituruna/PR \\
\hline 3 - Asteca Baixo Sabugo Fino & yellow & dent & 73 & medium & medium & short & Porto União/SC \\
\hline 4 - Asteca Sabugo Fino & yellow-orange & dent & 76 & medium & medium & medium & $\begin{array}{l}\text { São João do } \\
\text { Triunfo/PR }\end{array}$ \\
\hline 5 - Astecão Antigo & yellow & dent & 75 & medium & long & medium & Bituruna/PR \\
\hline $6-\mathrm{BR} 473^{6}$ & yellow-orange & semi-dent & 69 & medium & medium & medium & Porto União/SC \\
\hline $7-\mathrm{BR} 106^{7}$ & yellow-orange & dent & 73 & medium & long & medium & Bituruna/PR \\
\hline 8 - Cabo Roxo ${ }^{4}$ & yellow & dent & 74 & long & medium & medium & $\begin{array}{l}\text { São João do } \\
\text { Triunfo/PR }\end{array}$ \\
\hline 9 - Caiano & yellow-orange & dent & 78 & medium & medium & medium & Bituruna/PR \\
\hline $10-\mathrm{C} 408 \times \mathrm{AG}^{8}$ & yellow-orange & dent & 71 & medium & medium & medium & Rio Azul/PR \\
\hline 11 - Carioca & yellow & dent & 75 & medium & medium & medium & Bituruna/PR \\
\hline 12 - Comum Antigo x Sabugo Fino & yellow-orange & dent & 73 & medium & long & medium & Rio Azul/PR \\
\hline 13 - Cravinho do Prestupa & yellow-orange & dent & 76 & short & medium & short & Bituruna/PR \\
\hline 14 - Cravinho Sabugo Grosso & yellow-orange & dent & 78 & medium & medium & medium & $\begin{array}{l}\text { Cruz } \\
\text { Machado/PR }\end{array}$ \\
\hline 15 - Cunha Amarelo & yellow-orange & dent & 73 & medium & long & medium & Rio Azul/PR \\
\hline 16 - Dente de Cotia & yellow & dent & 76 & medium & medium & medium & $\begin{array}{l}\text { Cruz Machado/ } \\
\text { PR }\end{array}$ \\
\hline 17 - Ivo Agostiniak & yellow-orange & dent & 76 & medium & long & medium & $\begin{array}{l}\text { Cruz } \\
\text { Machado/PR }\end{array}$ \\
\hline 18 - Мacaco & yellow-orange & dent & 75 & medium & long & medium & Porto União/SC \\
\hline
\end{tabular}


Table 1 (cont.)

\begin{tabular}{|c|c|c|c|c|c|c|c|}
\hline Accessions & $\begin{array}{l}\text { Endosperm } \\
\text { color }\end{array}$ & Kernel type & $\begin{array}{l}\text { Flowering times } \\
\text { (days) }\end{array}$ & $\begin{array}{l}\text { Length kernel } \\
(\mathrm{mm})\end{array}$ & $\begin{array}{l}\text { Width kernel } \\
(\mathrm{mm})\end{array}$ & $\begin{array}{c}\text { Thickness } \\
\text { kernel (mm) }\end{array}$ & City/State ${ }^{10}$ \\
\hline 19 - Maia & yellow-orange & dent & 76 & medium & long & medium & $\begin{array}{l}\text { Cruz } \\
\text { Machado/PR }\end{array}$ \\
\hline 20 - Milho Faxinal & yellow-orange & dent & 73 & medium & medium & medium & $\begin{array}{l}\text { São Mateus do } \\
\text { Sul/PR }\end{array}$ \\
\hline 21 - Milho Sem Nome & yellow-orange & semi-dent & 74 & medium & medium & medium & Palmeira/PR \\
\hline 22 - Ouro Verde & yellow-orange & dent & 73 & medium & medium & medium & Iratí/PR \\
\hline 23 - Palha Roxa & yellow-orange & dent & 74 & long & long & medium & Porto União/SC \\
\hline 24 - Palha Roxa & yellow & dent & 73 & long & long & short & $\begin{array}{l}\text { São João do } \\
\text { Triunfo/PR }\end{array}$ \\
\hline 25 - Sete Variedades & yellow-orange & dent & 73 & medium & medium & medium & Porto União/SC \\
\hline 26 - Sol da Manhã & yellow-orange & semi-dent & 69 & short & medium & medium & Palmeira/PR \\
\hline 27 - Azcril & yellow & dent & 76 & medium & long & medium & $\begin{array}{l}\text { Cruz } \\
\text { Machado/PR }\end{array}$ \\
\hline $28-$ Cabo Roxo ${ }^{5}$ & segregant & dent & 76 & medium & long & medium & $\begin{array}{l}\text { São João do } \\
\text { Triunfo/PR }\end{array}$ \\
\hline 29 - Pintado & yellow-orange & dent & 72 & medium & long & medium & Porto União/SC \\
\hline 30 - Sangue do Adão $^{2}$ & yellow-orange & dent & 75 & medium & medium & medium & Bituruna/PR \\
\hline $31-$ IAPAR $51^{1}$ & yellow & dent & 73 & medium & medium & medium & $\begin{array}{l}\text { IAPAR, Lon- } \\
\text { drina /PR }\end{array}$ \\
\hline 32 - Amarelão Antigo & yellow & dent & 77 & medium & long & medium & Porto União/SC \\
\hline 33 - Amarelão Bazonni & yellow-orange & dent & 80 & long & long & medium & Porto União/SC \\
\hline 34 - Amarelão Diwietz & yellow & dent & 74 & medium & medium & medium & Porto União/SC \\
\hline 35 - Amarelo Antigo do Valdivino & yellow-orange & dent & 80 & medium & long & medium & Bituruna/PR \\
\hline 36 - Amarelo do Tião & yellow-orange & dent & 79 & medium & long & short & Rebouças/PR \\
\hline 37 - Amarelo Graudo & yellow-orange & dent & 77 & medium & long & medium & Rio Azul/PR \\
\hline 38 - Amarelo Taguari & yellow-orange & dent & 79 & medium & long & medium & Rio Azul/PR \\
\hline 39 - Antigo 30 anos & yellow-orange & dent & 82 & medium & long & medium & Iratí/PR \\
\hline 40 - Antigo Linha 5 & yellow-orange & dent & 80 & medium & long & short & Iratí/PR \\
\hline 41 - Cravinho do Zeno & orange & dent & 79 & medium & medium & short & $\begin{array}{l}\text { Cruz Machado/ } \\
\text { PR }\end{array}$ \\
\hline 42 - Dente de Rato & yellow-orange & dent & 80 & medium & medium & medium & Iratí/PR \\
\hline 43 - Encantilado & yellow-orange & dent & 83 & medium & long & medium & $\begin{array}{l}\text { Cruz } \\
\text { Machado/PR }\end{array}$ \\
\hline 44 - Linha Paraná & yellow-orange & dent & 81 & long & long & medium & $\begin{array}{l}\text { Cruz } \\
\text { Machado/PR }\end{array}$ \\
\hline 45 - Milho Antigo & yellow-orange & dent & 78 & medium & long & medium & Palmeira/PR \\
\hline 46 - Milho Antônios I & yellow-orange & dent & 80 & medium & long & medium & Iratí/PR \\
\hline 47 - Milho Caxoeira & yellow-orange & dent & 78 & medium & long & medium & $\begin{array}{l}\text { São João do } \\
\text { Triunfo/PR }\end{array}$ \\
\hline 48 - Milho Fabrício Darci & yellow-orange & dent & 78 & medium & long & medium & $\begin{array}{l}\text { São João do } \\
\text { Triunfo/PR }\end{array}$ \\
\hline 49 - Milho Ferrinho & yellow-orange & semi-dent & 77 & short & medium & medium & $\begin{array}{l}\text { União da } \\
\text { Vitória/PR }\end{array}$ \\
\hline 50 - Milho Gropires & yellow-orange & dent & 78 & medium & long & medium & Palmeira/PR \\
\hline 51 - Milho Pires & yellow-orange & dent & 78 & long & medium & medium & $\begin{array}{l}\text { Cruz Machado/ } \\
\text { PR }\end{array}$ \\
\hline 52 - Palha Roxa Alicheski & yellow & dent & 78 & medium & long & medium & $\begin{array}{l}\text { São João do } \\
\text { Triunfo/PR }\end{array}$ \\
\hline 53 - Pirulim do Tadeu & yellow-orange & dent & 80 & long & medium & medium & Bituruna/PR \\
\hline 54 - Indígena ${ }^{3}$ & yellow & dent & 83 & medium & medium & medium & $\begin{array}{l}\text { Cruz } \\
\text { Machado/PR }\end{array}$ \\
\hline 55 - IAPAR $50^{1}$ & yellow-orange & dent & 78 & medium & long & medium & $\begin{array}{l}\text { IAPAR, Lon- } \\
\text { drina/PR }\end{array}$ \\
\hline 56 - Antigo & segregant & dent & 78 & medium & long & medium & Rio Azul/PR \\
\hline 57 - Antigo Venglarek & segregant & dent & 75 & medium & long & medium & $\begin{array}{l}\text { São Mateus do } \\
\text { Sul/PR }\end{array}$ \\
\hline 58 - Asteca Branco Sabugo Fino & white & dent & 75 & long & long & short & $\begin{array}{l}\text { São João do } \\
\text { Triunfo/PR }\end{array}$ \\
\hline 59 - BR $451(\mathrm{QPM})^{9}$ & white & dent & 71 & medium & medium & medium & Rebouças/PR \\
\hline 60 - Branco Comum & white & dent & 75 & medium & long & medium & Rio Azul/PR \\
\hline
\end{tabular}


Table 1 (cont.)

\begin{tabular}{|c|c|c|c|c|c|c|c|}
\hline 61 - Branco do Ferraz & white & dent & 78 & medium & medium & medium & $\begin{array}{l}\text { São Mateus do } \\
\text { Sul/PR }\end{array}$ \\
\hline 62 - Bromado & white & dent & 71 & medium & medium & medium & $\begin{array}{l}\text { São João do } \\
\text { Triunfo/PR }\end{array}$ \\
\hline 63 - Bugre Branco & white & dent & 75 & medium & very long & medium & Rio Azul/PR \\
\hline 64 - Casano & white & dent & 79 & short & very long & medium & Rio Azul/PR \\
\hline 65 - Cinquentinha & white & dent & 75 & medium & medium & medium & $\begin{array}{l}\text { Cruz } \\
\text { Machado/PR }\end{array}$ \\
\hline 66 - Milho Branco do Vicente Huk & white & dent & 73 & medium & medium & medium & Rebouças/PR \\
\hline 67 - Oito Carreiras & white & dent & 76 & medium & very long & medium & $\begin{array}{l}\text { Cruz Machado/ } \\
\text { PR }\end{array}$ \\
\hline 68 - Tostão Oito Carreiras & white & dent & 75 & short & very long & medium & Rio Azul/PR \\
\hline 69 - Asteca Branco & white & dent & 81 & medium & medium & medium & Rio Azul/PR \\
\hline 70 - Astecão Branco & segregant & dent & 80 & medium & long & medium & $\begin{array}{l}\text { São João do } \\
\text { Triunfo/PR }\end{array}$ \\
\hline 71 - Branco & segregant & dent & 84 & medium & long & medium & Rio Azul/PR \\
\hline 72 - Branco de Cercado & white & dent & 83 & medium & long & medium & Palmeira/PR \\
\hline 73 - Branco do Norte & white & dent & 81 & medium & long & medium & Iratí/PR \\
\hline 74 - Branco dos Borges & white & dent & 83 & medium & long & medium & Rebouças/PR \\
\hline 75 - Branco Mexicano & segregant & dent & 82 & medium & long & medium & Palmeira/PR \\
\hline 76 - Branco Lastek Dinart & white & dent & 83 & medium & long & medium & $\begin{array}{l}\text { São João do } \\
\text { Triunfo/PR }\end{array}$ \\
\hline 77 - Cunha Branco & white & dent & 83 & medium & long & medium & Iratí/PR \\
\hline 78 - Maizena & white & farinaceous & 80 & medium & long & medium & $\begin{array}{l}\text { Cruz Machado/ } \\
\text { PR }\end{array}$ \\
\hline 79 - Milho Branco Palha Roxa & segregant & dent & 81 & medium & long & medium & $\begin{array}{l}\text { Cruz Machado/ } \\
\text { PR }\end{array}$ \\
\hline 80 - Milho Mexicano & white & dent & 81 & medium & long & medium & $\begin{array}{l}\text { Cruz Machado/ } \\
\text { PR }\end{array}$ \\
\hline 81 - Tostão & white & dent & 79 & short & very long & medium & Rebouças/PR \\
\hline
\end{tabular}

${ }^{1}$ Improved variety developed at Instituto Agronômico do Paraná (IAPAR).

${ }^{2}$ Variety with red aleurone.

${ }^{3}$ Accessions with blue aleurone.

${ }^{4,5}$ Varieties with the same name, cultivated in same city, but planted by different local communities.

${ }^{6,7,8,9}$ Commercial varieties submitted to massal selection by local farmer for several years.

${ }^{10}$ Origin of maize accessions. PR indicates Paraná State and SC indicates Santa Catarina State.

tions. This is a limiting factor in the use of these germplasm in breeding programs.

The present collection, which represents a small part of the Brazilian maize germplasm, comprises 79 maize landraces cultivated by small regional landholder farmers of Paraná and Santa Catarina States (Figure 1) and maintained in reproductive isolation by traditional agriculture for many years of farmer-directed selection. This collection includes the dent and floury kernel types and also different kernel colors that are conditioned by endosperm (yellow, orange, yellow-orange, and white endosperm) or by pericarp and aleurone colors (colorless, red, and blue, and blotched in many tones) (Table 1). According to Nass and Paterniani (2000), color and kernel types and flowering time can be used in the germplasm evaluation. Six kernel types (dent, flint, popcorn, floury, sweet and waxy) have been described in maize (Bandel, 1987).

In maize, flowering time generally occurs between 40 and 100 days after germination, even though it is highly influenced by environmental conditions (Goodman and Smith, 1987). The maize landraces used in this manuscript showed a smaller variation in flowering time. They were

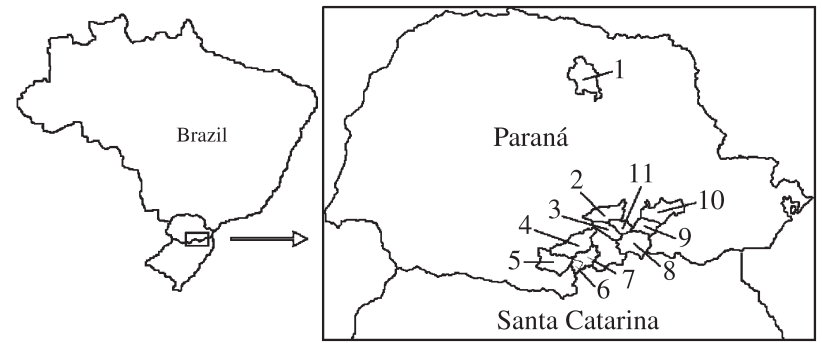

Figure 1 - Geographic localities of maize collection used in this study. 1, Londrina, PR (accessions 5 and 50); 2, Iratí (accessions 22, 39, 40, 42, 46, 73 and 77); 3, Rio Azul, PR (accessions 1, 10, 12, 15, 37, 38, 56, 60, 63, 64, 68, 69 and 71); 4, Cruz Machado, PR (accessions 14, 16, 17, 19, 27, 41, 43, 44, 51, 54, 65, 67, 78,79 and 80); 5, Bituruna, PR (accessions 2, 5, $7,9,11,13,30,35$, and 53); 6, Porto União, SC (accessions 3, 6, 18, 23, 25, 29, 32, 33 and 34); 7, União da Vitória, PR (accession 49); 8, São Mateus do Sul, PR (accessions 20, 57 and 61); 9, São João do Triunfo, PR (accessions 4, 8, 24, 28, 47, 48, 52, 58, 62, 70 and 76); 10, Palmeira, PR (accessions 21, 26, 45, 50, 72 and 75); 11, Rebouças, PR (accessions 36, $59,66,74$ and 81). The numbers are listed in Table 1. PR = Paraná State and $\mathrm{SC}=$ Santa Catarina State.

evaluated in a same locality and the flowering time occurred between 69 and 84 days (Figure 1, Table 1). 


\section{DNA extraction and amplification}

Total DNA was extracted from bulked leaves containing equivalent proportions of leave tissue from 15 plants for each population, for a total of 81 bulks. The DNA was extracted using the CTAB procedure (Doyle and Doyle, 1989). DNA samples were quantified in a fluorometer (DyNA-Quant-200, Hoeffer-Pharmacia) and the concentration adjusted to $10 \mathrm{ng} / \mu \mathrm{L}$. RAPD reactions were done in a volume of $15 \mu \mathrm{L}$ containing $1 \mathrm{x}$ PCR buffer (75 mM Tris- $\mathrm{HCl} \mathrm{pH} 9.0,50 \mathrm{mM} \mathrm{KCl}, 2.0 \mathrm{mM} \mathrm{MgCl}_{2}$, $20 \mathrm{mM}\left(\mathrm{NH}_{4}\right)_{2} \mathrm{SO}_{4}, 0.3 \mathrm{mM}$ of each dNTP (dCTP, dGTP, dTTP, dATP), $0.4 \mu \mathrm{M}$ of 10-mer primers (Operon Technologies), $0.7 \mathrm{U}$ of Taq polymerase (Biotools), and $20 \mathrm{ng}$ of template DNA. Amplifications were carried out in a PTC-100 Thermocycler (MJ Research) with the following program: 1 initial denaturation step at $94{ }^{\circ} \mathrm{C}$ for $2 \mathrm{~min}$ followed by 47 cycles at $94^{\circ} \mathrm{C}$ for $1 \mathrm{~min}, 38^{\circ} \mathrm{C}$ for $1.45 \mathrm{~min}$, and $72{ }^{\circ} \mathrm{C}$ for $2 \mathrm{~min}$ and a final cycle at $72{ }^{\circ} \mathrm{C}$ for $7 \mathrm{~min}$. The amplified products were separated by electrophoresis in $1.4 \%$ Methaphor (FMC Bioproducts) agarose in $1 \mathrm{x}$ TAE buffer (Tris-acetate $0.04 \mathrm{M}$ and EDTA $0.01 \mathrm{M} \mathrm{pH} \mathrm{7.5),}$ containing $0.15 \mu \mathrm{g} / \mu \mathrm{L}$ of ethidium bromide. The gels were photographed under UV light and the images transferred to a microcomputer for future analysis. A 100 base pairs DNA ladder (GIBCO BRL) was included in the gels as standard molecular weight.

\section{Morphological and molecular data analysis}

The morphological characteristics listed in Table 1 were evaluated in a randomized complete-block design with five replications. Each plot consisted of two $5 \mathrm{~m}$ rows spaced at $0.9 \mathrm{~m}$ between the rows, with a total of 40 plants. The experiment was conducted in the experimental field of IAPAR during the years 2000/2001.

Each RAPD product was assumed to represent a single locus and data were scored as the presence (1) or absence (0) of a DNA band. Only those fragments consistently amplified were considered for analysis. Genetic similarities were calculated according to the simple matching coefficient (Gover, 1985) and a dendrogram was created based on the UPGMA (unweighted pair-group method using arithmetical averages) method (Sneath and Sokal, 1973) of the NTSYS-pc (Numerical Taxonomy and Multivariate Analysis System for personal computers), Version 2.1 package (Rohlf, 2000). Estimates of the bootstrap standard deviation were based on 1000 samples using a simple matching coefficient (Gover, 1985). The calculations were performed with the Dboot version 1.1 (Coelho, 2001).

\section{Results and Discussion}

\section{RAPD marker analysis}

Preliminary studies involved screening 212 primers against the DNA of five plants from the maize landraces to

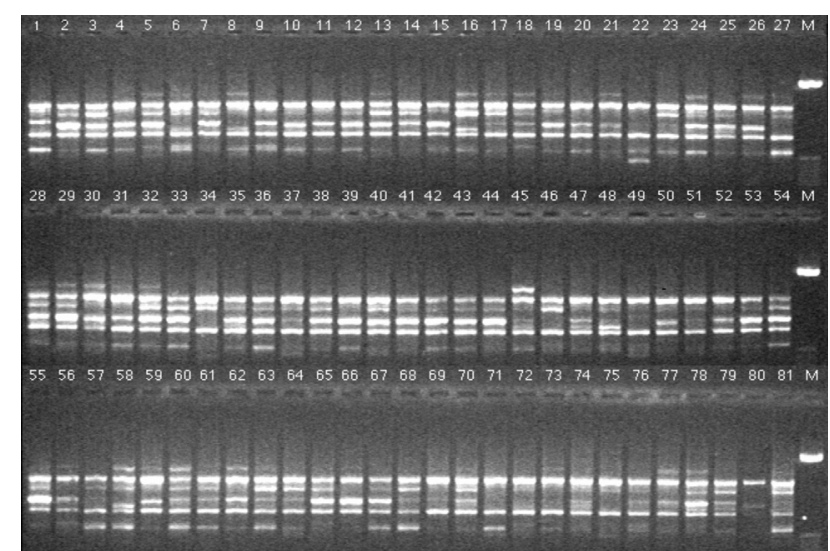

Figure 2 - RAPD gel profile with fragments generated by primer OPW-08 in 81 accessions of maize. Lines 1 through 81 refer to the collection listed in Table 1. M is 100 bp DNA size marker (Gibco BRL).

test their ability to produce polymorphism. One hundred and eighty primers (85\%) yielded either monomorphic or unreproducible fragments (data not shown). The remaining 32 primers provided reliable and consistent polymorphic bands and were then used to amplify genomic DNA of the 81 maize accessions (Table 1). A total of 255 fragments, in a range of 104 (OPAX-07) to 2270 (OPX-13) base pairs, were scored with an average of 8 fragments per primer (Table 2). Strong and weak bands were produced in the RAPD reactions. Weak bands result from low homology between the primer and the pairing site on the DNA strand (Thormann et al., 1994). The weak bands were, therefore, disregarded to increase analysis precision. The pattern of amplified products generated with OPW-08 primer is shown in Figure 1.

The percentage of polymorphism (72\%) was similar to the values observed in the genetic analysis of endogamic maize lines (Lanza et al., 1997), in the study of maize hybrids (Heun and Helentjaris, 1993), and in the evaluation of genetic polymorphism among varieties of native American maize as reported by Moeller and Schall (1999). RAPD markers have also been extensively used in assessing genetic variation in other plant species such as Colocasia esculenta (Irvin et al., 1998), Vigna species (Santala et al., 1998), and potato germplasms (Forapani et al., 1999).

Dendrogram stability is an important consideration in genetic variability studies. In this study, the number of bands necessary to obtain a stable classification of all accessions was estimated using bootstrap analysis. The calculations of bootstrap showed that the rate of decrease was comparatively minimal beyond 150 markers (Figure 3) suggesting that 255 markers are adequate for assessing the genetic variation present in the 79 landraces and two improved varieties (coefficient of variation $=2.8 \%$ ). Similar results have been revealed in other maize studies. Analysis of genetic diversity involving endogamic maize lines showed that 150 polymorphic fragments were sufficient to stabilize the dendrogram (Lanza et al., 1997; Pejic et al., 
Table 2 - Decamer oligonucleotide primers (Operon Technologies Inc.) selected for RAPD analysis of 81 accessions of maize including number of fragments for each primer and number and size of polymorphic fragment produced.

\begin{tabular}{|c|c|c|c|c|c|}
\hline \multirow[t]{2}{*}{ Primers } & \multirow[t]{2}{*}{ Sequence (5'-3') } & \multirow[t]{2}{*}{$\mathrm{Nf}$} & \multirow[t]{2}{*}{$\mathrm{Np}$} & \multicolumn{2}{|c|}{$\begin{array}{c}\text { Fragment size in } \\
\text { base pair }\end{array}$} \\
\hline & & & & Larger & Smaller \\
\hline OPAD-06 & AAGTGCACGG & 9 & 6 & 1359 & 826 \\
\hline OPAD-14 & GAACGAGGGT & 8 & 7 & 1653 & 978 \\
\hline OPAK-15 & ACCTGCCGTT & 6 & 4 & 2004 & 1462 \\
\hline OPAM-01 & TCACGTACGG & 9 & 7 & 1948 & 709 \\
\hline OPAR-02 & CACCTGCTGA & 9 & 9 & 1931 & 1364 \\
\hline OPAR-04 & CCAGGAGAAG & 7 & 7 & 1789 & 979 \\
\hline OPAR-05 & CATACCTGCC & 9 & 9 & 2059 & 1481 \\
\hline OPAR-11 & GGGAAGACGG & 4 & 1 & 1809 & 1464 \\
\hline OPAR-15 & ACACTCTGCC & 4 & 4 & 1909 & 1628 \\
\hline OPAR-16 & CCTTGCGCCT & 7 & 6 & 2000 & 1240 \\
\hline OPAT-08 & TCCTCGTGGG & 10 & 10 & 1441 & 774 \\
\hline OPAU-12 & CCACTCGTCT & 7 & 5 & 1682 & 854 \\
\hline OPAV-03 & TGTAGCCGTG & 6 & 5 & 2064 & 1318 \\
\hline OPAV-13 & CTGACTTCCC & 8 & 7 & 2071 & 1427 \\
\hline OPAV-19 & CTCGATCACC & 6 & 6 & 1309 & 381 \\
\hline OPAW-07 & AGCCCCCAAG & 8 & 4 & 1667 & 174 \\
\hline OPAW-08 & CTGTCTGTGG & 6 & 4 & 1500 & 813 \\
\hline OPAW-10 & GTTGTTTGCC & 8 & 8 & 2004 & 1513 \\
\hline OPAW-11 & CTGCCACGAG & 10 & 5 & 1576 & 861 \\
\hline OPAW-14 & GGTTCTGCTC & 7 & 3 & 1987 & 794 \\
\hline OPAW-19 & GGACACAGAG & 8 & 6 & 1375 & 693 \\
\hline OPAX- 07 & ACGCGACAGA & 8 & 3 & 1261 & 104 \\
\hline OPAX- 10 & CCAGGCTGAC & 8 & 5 & 1619 & 481 \\
\hline OPP- 05 & CCCCGGTAAC & 11 & 9 & 1252 & 1153 \\
\hline OPP-14 & CCAGCCGAAC & 4 & 2 & 1600 & 742 \\
\hline OPE-18 & CGACTGCAGA & 8 & 6 & 1198 & 843 \\
\hline OPW-08 & GACTGCCTCT & 10 & 8 & 1532 & 968 \\
\hline OPW-09 & GTGACCGAGT & 8 & 5 & 1941 & 524 \\
\hline OPW-13 & CACAGCGACA & 10 & 6 & 2270 & 925 \\
\hline OPY-04 & GGCTGCAATG & 13 & 6 & 2044 & 673 \\
\hline OPY-09 & AGCAGCGCAC & 8 & 3 & 1934 & 686 \\
\hline OPY-10 & CAAACGTGGG & 11 & 8 & 1757 & 534 \\
\hline Total & & 255 & 184 & & \\
\hline
\end{tabular}

Nf: Number of fragment.

$\mathrm{Np}$ : Number of polymorphic fragment.

1998). However, according to Thormann et al., (1994), the number of bands giving a particular variation coefficient depend on the nature of the genotypes analyzed.

\section{Genetic relationships among maize landraces}

This research was done to characterize the extent of genetic variation in 79 maize landraces and two commer-

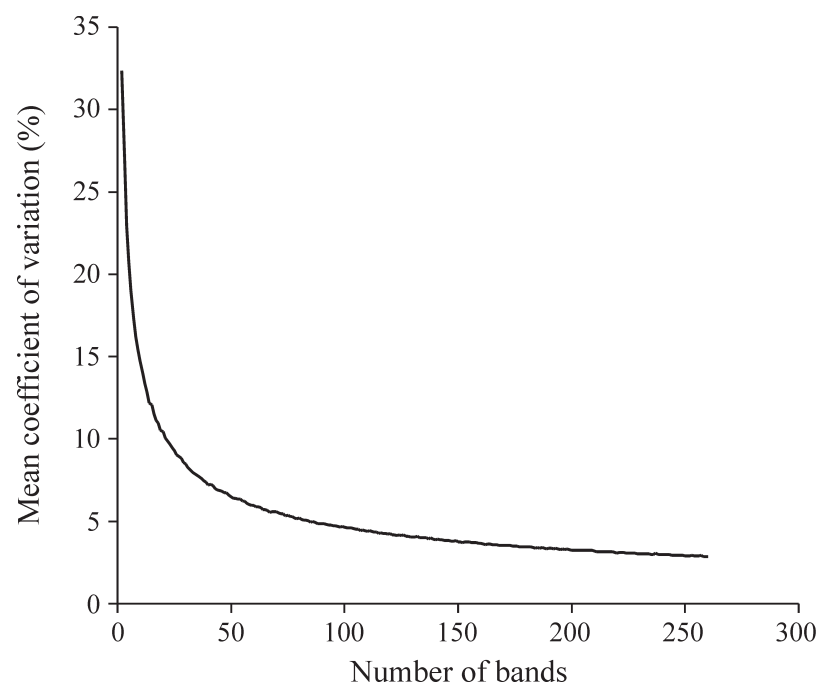

Figure 3 - Sample variance of genetic similarity estimation for 81 maize accessions as depicted by the relationship between the mean coefficient of variation (\%) and number of bands derived from a bootstrap procedure.

cial varieties grown in Southern Brazil using RAPD markers. The UPGMA dendrogram based on the similarity matrix associated the 79 landrace accessions into two major clusters. There were close relationships among accessions with yellow and yellow-orange endosperm, which clustered with a similarity coefficient of between 0.82 and 0.90 . The group containing mostly accessions with white endosperm displayed a comparable range of genetic similarity. The other five accessions remained isolated in the dendrogram (Table 1, Figure 4). Carvalho et al. (2002) showed similar results by using inter simple sequence repeat (ISSR) markers in the same maize collection. The similarity values and polymorphic index were greater for ISSR than for RAPD markers. ISSR and RAPD markers were also used to estimate the polymorphic indexes of diploid, tetraploid, and hexaploid wheat species (Nagaoka and Ogihara, 1997) and varieties of Oriza sativa (Beverley et al., 1997). Moeller and Schaal (1999), using RAPD markers in Native American maize collections of Great Plains, showed a similarity index that varied from 0.44 to 0.80 . This high level of genetic variability suggested that many maize accessions had been traded into those regions or migrated with indigenous tribes who had begun maize agriculture in other localities. The maize landraces included in this research showed low variability ( 0.78 to 0.91$)$, in comparison to American maize of the Great Plains, possibly because it represents just a small fraction of the Brazilian maize core collection.

Studies comprising 28 open pollinated varieties of maize (Parentoni et al., 2001) showed that there was an association between the dendrogram obtained by RAPD markers and morphological characteristics. The author found that flint and semi-flint genotypes as well as the dent and semi-dent germplasm were placed in different groups by RAPD markers. 
Good agreement between known pedigree obtained by morphological data and phylogeny among open pollinated varieties estimated by RAPD have been reported by Yu and Pauls (1993) and Kongkiatngan et al. (1996). The associations revealed in cluster 1 show a high genetic similarity between the yellow and yellow-orange maize accessions studied (Figure 4). The Asteca Antigo do Prestupa, Astecão Antigo, and Asteca Baixo Sabugo Fino landraces, all of Aztec origin, formed a small group, which also display similar kernel morphology and flowering time (Table 1). The same pattern is observed for the Antigo 30 anos, Antigo Linha 5, Milho Antigo, Comum Antigo x Sabugo Fino, and Amarelão Antigo landraces. These landraces have characteristics that were found in the antique germplasm.

Accession C $408 \times$ AG was found isolated in the dendrogram. It was the result of crossing two commercial hybrids that were maintained by small landholder farmers for an extended period of time. The Maia landrace and the improved variety IAPAR 50 were associated with high genetic similarity coefficient $(0.87)$. This association is consistent with their common origin since both the Maia and IAPAR 50 accessions contain the Maya gene pool.

The Cunha Amarelo, Sangue de Adão, Amarelo Graudo, Dente de Cotia, Ivo Agostiniak, Amarelão Basonni, Amarelo Taguari, Cabo Roxo and Pintado landraces were associated in a small group. These accessions display similar kernel characteristics and flowering time, and except for the Sangue de Adão landrace, which shows red seeds that are conditioned by red pericarp, all others have yellow seeds (Figure 4, Table 1).

Genetic associations in cluster 2 reveal high similarity among the accessions. In this cluster, seven accessions grouped together, of which five (Branco Comum, Bugre Branco, Casano, Oito Carreiras and Tostão) showed similar kernel characteristics and flowering time and two (Antigo Venglarek and Antigo) segregate for endosperm color (Figure 4, Table 1). The Oito Carreiras and Tostão landraces were very close, with a similarity coefficient of 0.90 . Both accessions display eight-row ears and very long kernel width, characteristics that are also observed in the Hickory King race introduced in Brazil from United States (Paterniani, 2000). It is possible that Oito Carreiras and Tostão are derived from the Hickory King race. Other accessions of cluster 2 that share similar kernel characteristics and flowering time were also very close by RAPDs, revealing coefficients of genetic similarities that ranged from 0.86 to 0.88 (Figure 4 , Table 1 ).

The highest genetic similarity (0.91) was observed between the Branco Lastek Dinart and Cunha branco landraces. These accessions have been cultivated in distinct regions by unrelated small farmers and are known by different names. In contrast, two other accessions, Astecão Branco and Asteca Branco that have been treated by similar names were less related by RAPD showing a similarity of

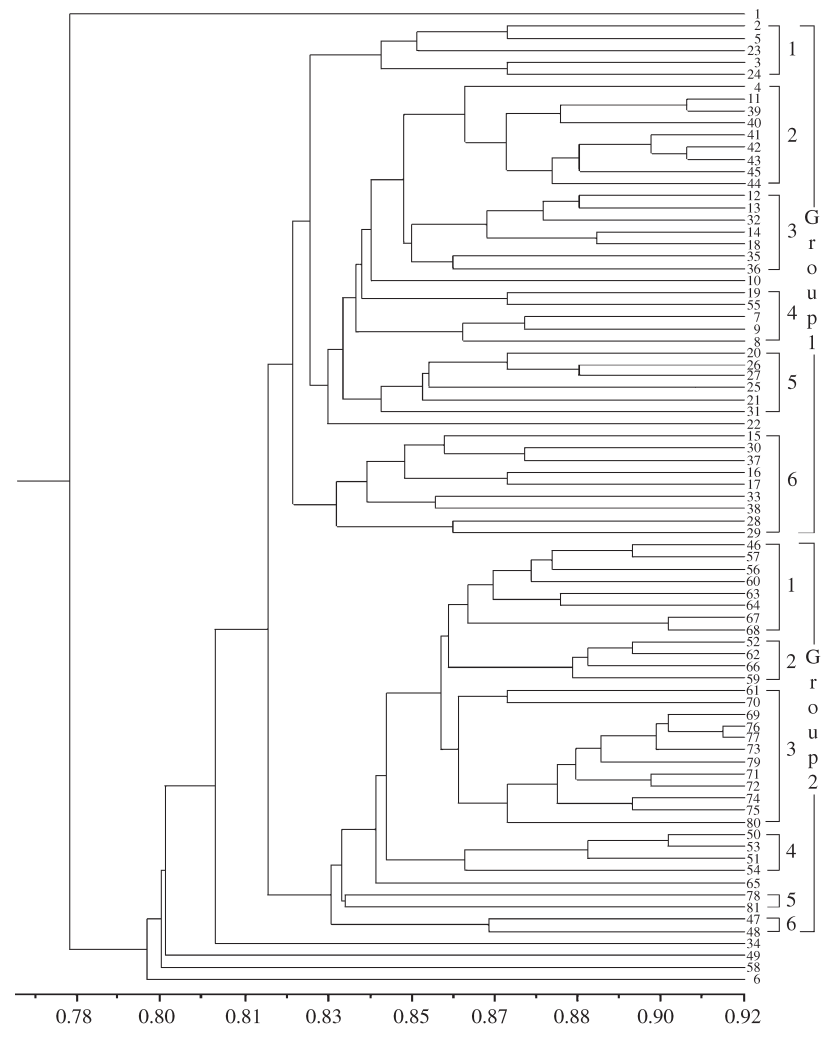

Figure 4 - Dendrogram of 81 maize accessions constructed using UPGMA method based on a similarity matrix produced with simple matching coefficients. Numbers 1 through 81 refer to the collection listed in Table 1.

0.85. Gimenes and Lopes (2000) reported similar results by using isoenzyme analysis. The authors studied 15 maize populations derived from three indigenous maize races and observed that there was no connection between the accessions name and the genetic relationships. Therefore accessions evaluation by molecular markers is important in germplasm classification to avoid the replication of genetic materials.

The Amarelão Diwietz, Milho Ferrinho, Asteca Branco Sabugo Fino, BR 473, and Asteca landraces appeared isolated from other accessions in the dendrogram (Figure 4, Table 1). The Asteca landrace, which showed the lowest similarity to the other accessions $(0.78)$, has a uncertain origin and it seems derived from a sample collected a few years ago by small landholder farmer.

The several small groups formed into each cluster revealed some genetic divergence within the yellow and within the white landraces. This is in line with the observations of Paterniani (2000). According to this author, the Brazilian maize landraces are derived from crossing introductions from United States (at different times in the past) and maize types cultivated for an extended period of time by indigenous tribes and European colonizers after the discovery of the American Continent. In the middle of the $18^{\text {th }}$ century, yellow dent germplasm was introduced to Brazil 
from the United States, while the white dent germplasm was recently introduced with the Hickory King variety. Doebley et al. (1988) reported that yellow dent, white dent, and Hickory King are races derived from Southern United States dent types. These facts explain the separation of yellow and white landraces by RAPD.

The landraces analyzed in this research have been used by small-scale farmers according to endosperm color. The white landraces are mainly used for flour manufacturing for human consumption and the yellow accessions are generally used in animal nutrition. The farmers consider that the planting of the landraces in small areas is less expensive than the commercially improved hybrids. Therefore, genetic improvement of this germplasm is important for traditional agriculture maintenance developed by the small landholder farmers from Paraná and Santa Catarina states.

In conclusion, the simplicity of laboratory assays for RAPD is an attractive method for the analysis of genetic diversity among maize landraces. The polymorphism detected among the accessions can be used in breeding programs to maximize the use of genetic resources.

\section{Acknowledgements}

The authors thank the farming families and the Assessoria e Serviços a Projetos em Agricultura Alternativa (AS-PTA) for supplying the samples of the landrace varieties. Thanks are also due to the Coordenação de Aperfeiçoamento de Pessoal de Nível Superior (CAPES) and Universidade Estadual de Londrina for funding and to Dr. Alberto José Prioli of Universidade Estadual de Maringá for helping in the statistical analysis.

\section{References}

Abadie T, Cordeiro CMT, Andrade RV, Magalhães JR and Parentoni SN (2000) A coleção nuclear de germoplasma de milho no Brasil. In: Udry CW and Duarte W (eds) Uma História Brasileira do Milho: O Valor dos Recursos Genéticos. Paralelo 15, Brasília, pp 65-77.

Bandel G (1987) Genética. In: Paterniani E and Viegas GP (orgs) Melhoramento e Produção do Milho. Fundação Cargill, Campinas, pp 111-133.

Bernardo R (1994) Prediction of single-cross performance using RFLPs and information from related hybrids. Crop Science 34:20-25.

Berveley JP, John Newbury H, Michael TJ and Brian VF (1997) Contrasting genetic diversity relationship are revealed in rice Oriza sativa (L.) using different marker types. Mol Breed 3:115-125

Carvalho VP, Ruas PM, Ruas CF, Ferreira JM and Moreira RMP (2002) Assessment of genetic diversity in maize (Zea mays L.) landraces using inter simple sequence repeat (ISSR) markers. Crop Breeding and Applied Biotechnology 2:557568.

Coelho ASG (2001) DBOOT - Avaliação dos erros associados a estimativas de distâncias/similaridades genéticas através do procedimento de bootstrap com número variável de marcadores, v. 1.1. Departamento de Biologia Geral, Instituto de Ciências Biológicas, Universidade Federal de Goiás, Goiânia, GO.

Colombo C, Second G and Charrier A (2000) Diversity within American cassava germplasm based on RAPD markers. Genetics and Molecular Biology 23:189-199.

Crossa J, Taba S, Eberhart SA. Breeting P and Vencovsky R (1994) Pratical considerations for maintaining germplasm in maize. Theoretical and Applied Genetic 89:89-95.

Doebley JF, Goodman MM and Stuber CW (1985) Isozyme variation in the races of maize from Mexico. American Journal of Botany 75:629-639.

Doebley JF, Wendel JD, Smith JSC, Stuber CW and Goodman MM (1988) The origin of Cornbelt maize: The isozyme evidence. Economic Botany 42:120-131.

Dos Santos JB, Nienhuis J, Skroch P, Tivang J and Slocum MK (1994) Comparison of RAPD and RFLP genetic markers in determining genetic similarity among Brassica oleracea L. genotypes. Theoretical and Applied Genetic 87:909-915.

Doyle JJ and Doyle JL (1987) Isolation of plant DNA from fresh tissue. Focus 12:13-15.

Ferreira ME and Grattapaglia D (1996) Introdução ao uso de marcadores moleculares em análise genética. 2nd ed. EMBRAPA-CENARGEN, Brasília, pp 121-130.

Forapani S, Carboni A, Castellani E, Mandolino G and Ranalli P (1999) RAPD markers for potato germplasm characterization. Journal of Genetic \& Breeding 53:143-147.

Gimenes MA and Lopes CR (2000) Isoenzimatic variation in the germplasm of Brazilian races of maize (Zea mays L.). Genetic and Molecular Biology 23:375-380.

Goodman MM and Smith JSC (1987) Botânica. In: Paterniani E and Viegas GP (orgs) Melhoramento e Produção do Milho. Fundação Cargill, Campinas, pp 41-78.

Gover JC (1985) Measures of similarity, dissimilarity, and distance. In: Kots S and Johnson NL (eds) Encyclopedia of Statistical Sciences, v. 5, New York, pp 397-405.

Gunter LE, Tuskan GA and Wullschleger SD (1996) Diversity among populations of switchgrass based on RAPD markers. Crop Science 36:1017-1022.

Heun M and Helentjaris T (1993) Inheritance of RAPDs in $F_{1}$ hybrids of corn. Theoretical and Applied Genetic 85:961-968.

Irvin SV, Kaufusi P, Banks K, de la Penha R and Cho JJ (1998) Molecular characterization of taro (Colocasia esculenta) using RAPD markers. Euphytica 99:183-189.

Kongkiatngam P, Waterway MJ, Coulman BE and Fortin MG (1996) Genetic variation among cultivars of red clover (Trifolium pratence L.) detected by RAPD markers amplified from bulk genomic DNA. Euphytica 89:355-361.

Lankey KR, Hallauer AR and Kahler AL (1997) Allelic difference at enzyme loci and hybrids performance in maize. Journal of Heredity 78:231-234.

Lanza LLB, De Souza Jr CL, Ottoboni LMM, Vieira LMC and De Souza AP (1997) Genetic distance of inbred lines and prediction of maize single-cross performance using RAPD markers. Theoretical and Applied Genetic 94:1023-1030.

Lashermes P, Trouslot P, Anthony F, Combes MC and Charrier A (1996) Genetic diversity for RAPD markers between cultivated and wild accessions of Coffea arabica. Euphytica 87:59-64. 
Lee M, Goldhalk FB, Lamkey KR and Wodmar WW (1989) Association of restriction fragment length polymorphism among maize inbreeds with agronomic performance of their crosses. Crop Science 29:1067-1071.

Machado AT, Pereira MB, Pereira ME, Machado CTT and Médice LE (1998) Avaliação de variedades locais melhoradas de milho em diferentes regiões do Brasil. In: Soares AC, Machado AT, Silva BM and von der Weid JM (eds) Milho Crioulo, Conservação e Uso da Biodiversidade. AS-PTA, Rio de Janeiro, pp 93-106.

Marsan PA, Egidy G, Monfredini G, Disilvestro S and Motto M (1993) RAPD markers in maize genetic-analysis. Maydica 38:259-264.

Marshall DR (1977) The advantages and hazards of genetic homogeneity. Annals of the New York Academy of Sciences 287:1-20.

Moeller DA and Schaal BA (1999) Genetics relationships among native American maize accessions of the Great Plains assessed by RAPDs. Theoretical and Applied Genetic 99:1061-1067.

Nagaoka T and Ogihara Y (1997) Applicability of inter-simple sequence repeat polymorphisms in wheat for use as DNA markers in comparison to RFLP and RAPD markers. Theor Appl Genet 94:597-602.

Nass LL and Paterniani E (2000) Perspectivas do pré-melhoramento do milho. In: Udry CW and Duarte W (eds) Uma História Brasileira do Milho: O Valor dos Recursos Genéticos. Paralelo 15, Brasília, pp 43-63.

Nass LL, Pellicano IJ and Valois ACC (1993) Utilization of genetic resources for maize and soybean breeding in Brazil. Brazilian Journal of Genetics 16:983-988.

Parentoni SN, Magalhães JV, Pacheco CAP, Santos MX, Abadie T, Gama EEG, Guimarães PEO, Meirelles WF, Lopes MA, Vasconcelos MJV and Paiva E (2001) Heterotic groups based on yield-specific combining ability data and phylogenetic relationship determined by RAPD markers for 28 tropical maize open pollinated varieties. Euphytica 121:197-208.

Paterniani E (1998) Diversidade genética e raças de milho no Brasil. In: Soares AC, Machado AT, Silva BM and von der Weid JM (eds) Milho Crioulo, Conservação e Uso da Biodiversidade. AS-PTA, Rio de Janeiro, pp 28-31.

Paterniani E, Nass LL and Santos MX (2000) O valor dos recursos genéticos de milho para o Brasil: Uma abordagem histórica da utilização do germoplasma. In: Udry CW and Duarte W (eds) Uma História Brasileira do Milho: O Valor dos Recursos Genéticos. Paralelo 15, Brasília, pp 11-43.

Pejic I, Ajmore-Marsan P, Morgante M, Kozumplick V, Castiglioni P, Taramino G and Motto M (1998) Comparative analysis of genetic similarity among maize inbred lines detected by RFLPs, RAPDs, SSRs, and AFLPs. Theoretical Applied Genetic 97:1248-1255.

Prince SC, Kahler AL, Hallauer AR, Charmley P and Giegel DA (1986) Relationships between performance and multilocus heterozygozity at enzyme loci in single-cross hybrids of maize. Journal of Heredity 77:341-344.

Rohlf FJ (2000) NTSYS-pc Numerical Taxonomy and Multivariate Analysis System version 2.1. Owner's manual.

Samec P and Nasinec V (1996) The use of RAPD technique for the identification and classification of Pisum sativum L. genotypes. Euphytica 89:229-234.

Santala M, Power JB and Davey MR (1998) Genetic diversity in mung bean germplasm revealed by RAPD markers. Plant Breeding 117:473-478.

Sharma SK, Dawson IK and Waugh R (1995) Relationship among cultivated and wild lentils revealed by RAPD analysis. Theoretical and Applied Genetic 91:647-654.

Smith JSC, Goodman MM and Stuber CW (1985) Genetic variability within U.S. maize germplasm. I. Historically important lines. Crop Science 25:550-555.

Sneath PHA and Sokal RR (1973) Numerical Taxonomy. WH Freeman and Co, San Francisco, 573 pp.

Soares AC, Machado AT, Silva BM and von der Weid JM (1998) Milho Crioulo, Conservação e Uso da Biodiversidade. ASPTA, Rio de Janeiro, 185 pp.

Thormann CE, Ferreira ME, Camargo LEA, Tivang JG and Osborn TC (1994) Comparison of RFLP and RAPD markers for estimating genetic relationships within and among cruciferous species. Theoretical and Applied Genetic 88:973980.

Williams JGK, Kubelik AR, Livak KJ, Rafalski JA and Tingey SV (1990) DNA polymorphism amplified by arbitrary primers are useful as genetic markers. Nucleic Acids Research 18:6531-6535.

Wood D and Lanné JM (1999) Agrobiodiversity: Characterization, Utilization and Management, CAB Publishing, New York, $490 \mathrm{pp}$.

Yu KF and Pauls KP (1993) Rapid estimation of genetic relatedness among heterogeneous populations of alfalfa by random amplification of bulked DNA samples. Theoretical and Applied Genetic 86:788-794. 